\title{
OBITUARY
}

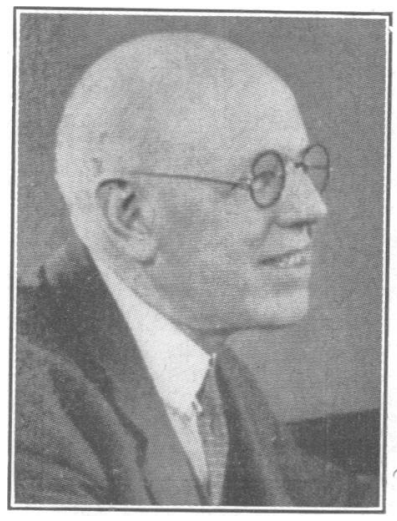

\section{WILLIAM FREEMAN SNOW}

Circumstances outside our control have hitherto prevented our adding, in this journal, our tribute to the memory of the late Dr. William Freeman Snow, Chairman of Directors of the American Social Hygiene Association, who died suddenly in a street of Bangor, Maine, in the early afternoon of Monday, June 12, 1950, thus quietly closing a life for which very many friends in his own and other countries are consciously grateful, and to which very many thousands unknowingly owe their escape from the misery engendered by the contraction of venereal disease.

It would require much more space than can be spared here to do justice to the great qualities which for over half a century made Snow beloved and respected in the world of those who have had the vision to realize that in combating venereal disease they may serve mankind perhaps even better than the surgeon who by brilliant dexterity saves many individual lives or the physician who makes erudite diagnoses and exposes the limitations of pharmacology. The present notice is for the benefit of readers who have not access to the December 1950 issue of the Journal of Social Hygiene which we understand will be a memorial number.

W. F. Snow was born in 1874 . After graduating B.A. in Chemistry at Stamford University in 1896, he proceeded to the M.D. degree in 1900 . After post-graduate work at Johns Hopkins and other institutions in the U.S.A. and abroad, he returned to Stamford and as Professor of Hygiene there and as Health Officer, California, rapidly acquired a reputation for energy, tact, and wisdom, characteristics which with others remained with him throughout his life. One might here add ingenuity and illustrate it with a story told of him by Dr. Wilbur A. Sawyer, Director of the International Health Division of the Rockefeller Foundation at a dinner given in Snow's honour in 1937 :

My comments will be on the earliest period of his rich professional life, the years in California before he came east in $1913 \ldots$. . Dr. Snow was working in the physiological laboratory and was called upon by President David Starr Jordan who brought with him a precious package. His pet monkey had eaten his wife's flypaper and had passed on, and President Jordan thought that Dr. Snow would like the skeleton. A few days later he came back to see the result and asked Dr. Snow how he had succeeded in cleaning the bones so perfectly and fitting them all in their proper places. Dr. Snow said: 'Oh, I buried it in an anthill and let the ants do the work'.

In 1913, Snow was persuaded by a band of pioneers, including President Charles W. Eliot, Dr. Prince Morrow, Dr. Edward L. Keyes, John D. Rockefeller, Jr. and President D. S. Jordan (just mentioned), to undertake the directorship of a new organization, the American Social Hygiene Association, which was formed to combine in one body the forces of religion, morality, social consciousness with medical, public health, educational, and legal 
activities. Through his work with the A.S.H.A., as adviser to the government of the U.S.A. during the two wars and as chairman of many other organizations with service to mankind as their object, Snow, to quote from notes supplied to the present writer by a close associate :

Brought together those medical, educational, and moral forces which today form the framework of the national social hygiene movement. His work during the past half-century has contributed notably to the changing public attitude in the United States and other countries towards sex in its relation to health and disease, and to individual and social wellbeing .... our entry into hostilities of 1917 found officials and citizens alike in the belief that the venereal diseases were unavoidable by-products of war. One of Dr. Snow's great achievements was the persuasion of the Secretaries of War and the Navy that this was not the case. His ideas of prevention of infection through education, medical care, wholesome leisuretime activities, and repression of prostitution were set up, demonstrated, and proved during his period of military service.

Amongst activities which perhaps more closely interest us on this side of the Atlantic may be mentioned Snow's chairmanship, from 1924-28, of the League of Nations Committee to study the Traffic in Women and Children, and his presidency, from 1947 to his death, of the International Union against Venereal Diseases. Concerning the former office an extract may be quoted from a letter sent to the dinner mentioned above by a British colleague, Mr. (now Sir) Sidney W. Harris, then Assistant Under-Secretary of State, Home Office, now Film Censor :

It was always a great pleasure to work with Dr. Snow. I admired his personality, his high sense of duty tempered by an equally high sense of humour, and his wonderful capacity for work.

It is comforting to know that on his last day of life Dr. Snow was feeling happy in the relief of his anxiety over the health of Mrs. Snow, to whom he had referred (at the dinner held in 1937) in the following characteristic terms :

Charles W. Eliot spoke much of the "Normal Satisfaction of Family Life'. Together with my life-long friend, counselor and companion-the lady who sits at my right-I have had the experience of guiding our parents through the grandparent stage ; and now we are being gently restrained from spoiling our children's children.

The writer of this tribute knew Snow for over thirty years, meeting him on various occasions at too-long intervals. Always he found him the same friendly, considerate, straight-dealing, earnest, wise, and particularly modest man. Like our late Harry Lauder, we all " love a man that is a man, a man both straight and fair" and such was William Freeman Snow.
L. W. H. 